\title{
Biology and physiology of Calbindin-D9k in female reproductive tissues: Involvement of steroids and endocrine disruptors Kyung-Chul Choi ${ }^{1}$, Peter CK Leung ${ }^{1}$ and Eui-Bae Jeung*2
}

\begin{abstract}
Address: ${ }^{1}$ Department of Obstetrics and Gynecology, British Columbia Children's and Women's Hospital, Child and Family Research Institute, University of British Columbia, Vancouver, BC V6H 3V5 Canada and ${ }^{2}$ Laboratory of Veterinary Biochemistry and Molecular Biology, College of Veterinary Medicine and Research Institute of Veterinary Medicine, Chungbuk National University, Cheongju, Chungbuk, 361-763 Republic of Korea

Email: Kyung-Chul Choi - kchoi@cw.bc.ca; Peter CK Leung - peleung@interchange.ubc.ca; Eui-Bae Jeung* - ebjeung@chungbuk.ac.kr

* Corresponding author

Published: 16 November 2005

Reproductive Biology and Endocrinology 2005, 3:66 doi:10.1/86/1477-7827-3-66

This article is available from: http://www.rbej.com/content/3/1/66

(c) 2005 Choi et al; licensee BioMed Central Ltd.

This is an Open Access article distributed under the terms of the Creative Commons Attribution License (http://creativecommons.org/licenses/by/2.0), which permits unrestricted use, distribution, and reproduction in any medium, provided the original work is properly cited.

Received: 02 September 2005

Accepted: 16 November 2005
\end{abstract}

\begin{abstract}
Although Calbindin-D9k (CaBP-9k), a cytosolic calcium binding protein which has calcium binding sites, is expressed in various tissues, i.e., intestine, uterus, and placenta, potential roles of this gene and its protein are not clearly understood. Uterine CaBP-9k may be involved in controlling myometrial activity related with intracellular calcium level and is not under the control of vitamin $D$ despite the presence of vitamin $D$ receptors. But, it is under the control of the sex steroid hormones, estrogen (E2) and progesterone (P4), in female reproductive systems including the uterus and placenta. Thus, in this review, we summarize recent research literature in regards to the expression and regulation of CaBP-9k in mammals and introduce the research data of recent studies by us and others.
\end{abstract}

\section{Introduction}

A 9-kilodalton cytosolic calcium-binding protein termed as Calbindin-D9k (CaBP-9k) belongs to a family of intracellular proteins which have high affinities for calcium, and has two calcium binding domains [1]. The full-length cDNA encoding the human CaBP-9k has been cloned using reverse transcription/PCR, which includes coding region of 79 amino acids, 57 nucleotides 5'- and 159 nucleotides 3 '-non-coding region, and a poly(A) tail (total 600 nucleotides in length) [2]. Further, our study revealed that this gene spans about $5.5-\mathrm{kb}$ and is localized on the $\mathrm{X}$-chromosome, consists of three exons and carries four Alu repeats [3]. In addition to its genomic structure, a sequence of 50 nucleotides downstream from the promoter showed an extensive homology to the estrogen response element (ERE) at the same location within the rat calbindin-D9k gene, suggesting that a two-nucleotide change within this region in human causes the gene to lack expression in human uterus and placenta [3].

It has been demonstrated that CaBP-9k is expressed in diverse mammalian tissues, i.e., intestine, uterus, kidney, and bone [4-7]. The functional role of CaBP-9k is involved in intestinal calcium absorption and its gene is regulated at the transcriptional or post-transcriptional level by 1,25-dihydroxyvitamin D3 $\left(1,25-(\mathrm{OH})_{2} \mathrm{D}_{3}\right)$, a hormonal form of vitamin $\mathrm{D}[8,9]$. This hormonal form caused a parallel increase in CaBP-9k mRNA and intestinal absorption of calcium in rats [10]. In addition, uterine CaBP-9k may be involved in controlling myometrial activity related with intracellular calcium level [6], but an exact role of CaBP-9k in the uterus is still under investigation by us and a few of other research groups. Recently, we demonstrated that uterine CaBP-9k is responsive to exog- 
A

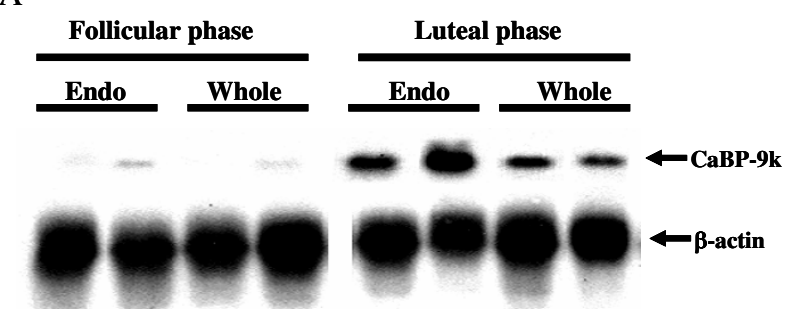

B

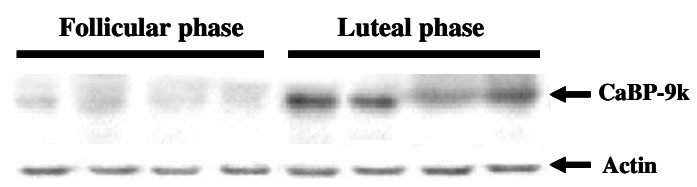

Figure I

Porcine CaBP-9k mRNA expression in the endometrium and whole uterus during an estrus cycle. To investigate a role of $\mathrm{CaBP}-9 \mathrm{k}$ in the tissue compartment of the pig uterus, the expression levels of CaBP-9k mRNA (A) and protein (B) were analyzed by Northern blot and immunoblot analyses. [Reproduced with permission from Yun S-M, Choi KC, Kim IH, An BS, Lee GS, Hong EJ, Son JH, Oh GT, Jeung E-B 2004 Calbindin- $D_{9 k}$ mRNA expression and regulation during estrus cycle in the pig uterus. Mol Reprod Dev 67: 25I lendash 256]

enous estrogen (E2) and can be a biomarker for environmental estrogenic chemicals, so called as "endocrine disruptors" in rat models [11-15]. Thus, in this review, we summarize recent research literature in regards to the expression and regulation of CaBP-9k in mammals and introduce updated research results by us and others.

\section{Uterine expression of CaBP-9k}

It has been demonstrated that CaBP-9k is mainly expressed in the endometrial stroma and myometrium of the uterus in non-pregnant rats $[16,17]$, whereas this gene is translocated into the epithelium of the uterus in pregnant rats [18]. However, it has been shown that the CaBP$9 \mathrm{k}$ is only expressed in the luminal and glandular epithelium of the endometrium, not in the myometrium and in the stromal cells of the endometrium in non-pregnant cows [19]. In contrast to the regulation of CaBP-9k in the intestine, CaBP-9k gene is not under the control of vitamin $\mathrm{D}$ in the uterus despite the presence of vitamin $\mathrm{D}$ receptors in this tissue. This gene appears to be under the control of the sex steroid hormones $[17,20,21]$.

There is a strong body of evidence that CaBP-9k is regulated by sex steroid hormones in the uterus of rats. Treatment of 21-day-old rats with E2 resulted in an increase in the expression of CaBP-9k mRNA up to 300-fold and its mRNA was shown to fluctuate in the uterus of rats during estrous cycle, where serum E2 level was also under fluctuation [22]. Although the expression of CaBP-9k mRNA is not detectable at diestrus when E2 level is at the lowest, this mRNA increases at proestrus and reaches the highest level at estrus in response to the rise in plasma E2 and then decreases at metestrus in the uterus of rats $[20,22]$. In addition, E2-dependent regulation of CaBP-9k gene was demonstrated. i.e., CaBP-9k synthesis decreased drastically in the uterus of ovariectomized rats, whereas it was greatly enhanced by low physiological doses of E2 in a dose-dependent manner by CaBP-radioimmunoassay (RIA) [17]. This E2-dependent regulation of CaBP-9k gene was also approved in the uterus of mature ovariectomized and immature rats by slot and Northern blot analysis $[23,24]$. In estrogen-primed ovariectomized rats, progesterone (P4) inhibited E2-induced CaBP-9k gene expression, which was completely abolished by coadministration of RU486, a P4 antagonist [20]. In the pregnant rats, $\mathrm{P} 4$ was shown to be responsible for downregulation of CaBP-9k gene in the uterus during early pregnancy [25]. In the ovariectomized (OVX) gilts, E2 treatment induced an increase in CaBP-9k mRNA level, whereas P4 administration to ovariectomized pigs decreased CaBP-9k mRNA levels [26]. Recently, we demonstrated that CaBP-9k mRNA and protein are dominantly expressed during luteal phase, indicating that $\mathrm{P} 4$ may play an important role in the up-regulation of CaBP$9 \mathrm{k}$ gene in the porcine uterus during luteal phase, which is unlike the condition in the rat uterus (Fig. 1) [27]. In this study, the porcine CaBP-9k may be dominantly expressed in the epithelium and glandular structure of the porcine uterus during luteal phase, suggesting that CaBP9k gene may also be differentially regulated during this cycle presumably by steroid hormones, especially up-regulated $\mathrm{P} 4$ level in this tissue [27]. In addition, a positive role of $\mathrm{P} 4$ on the expression of CaBP-9k has been demonstrated in the bovine uterus, which indicates that the expression of CaBP-9k was greatest during P4-dominated luteal phase of the bovine estrous cycle [19].

In contrast to the uterus of rats, the expression of CaBP-9k gene is not under strict $\mathrm{E} 2$ regulation in the uterus of mice. The uterus of mice has been demonstrated to express CaBP-9k and its level increases in this tissue during early pregnancy and implantation $[28,29]$. CaBP-9k mRNA is expressed in the endometrial epithelia, both luminal and glandular, in the uterus at the time of implantation, and in the luminal, but not in the glandular, epithelia on early pregnancy (day 5 of pregnancy). P4 enhanced CaBP-9k mRNA expression in the uterus, whereas E2 did not in the oophorectomized adult mice [28]. A higher expression of CaBP-9k mRNA was observed in the uterus of mice at diestrus and metestrus, whereas only basal level of its expres- 

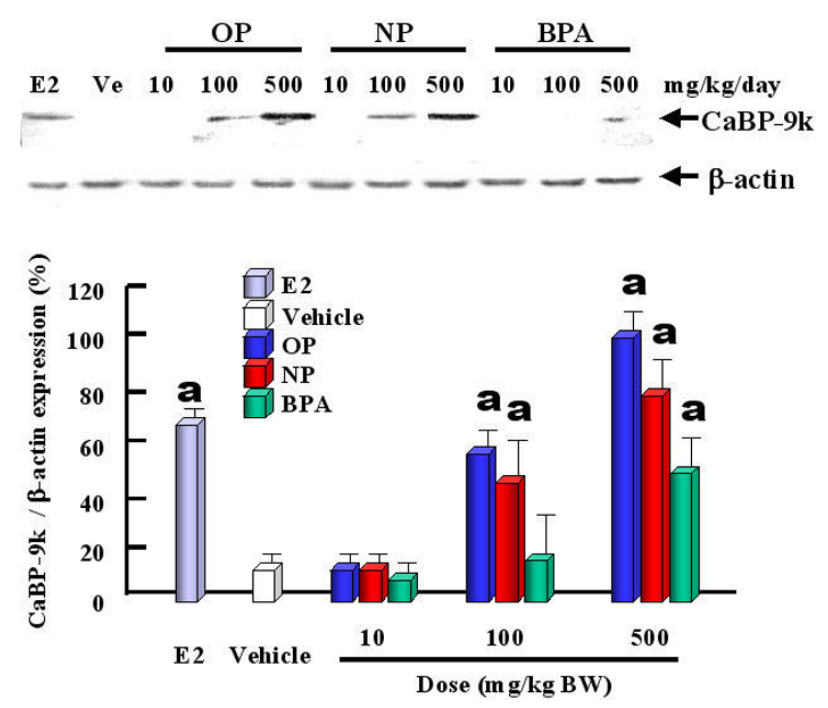

\section{Figure 2}

Induction of uterine CaBP-9k protein by estrogenic compounds, i.e., OP, NP and BPA was assessed in a dose-dependent manner at $24 \mathrm{~h}$ after final injection by immunoblot analysis. Data are presented as the mean \pm SD. a; significantly different compared with vehicle at $P<0.05$. [Reproduced with permission from An B-S, Choi KC, Kang SK, Hwang WS, Jeung EB 2003 Novel Calbindin-D9k protein as a useful biomarker for environmental estrogenic compounds in the uterus of immature rats. Reprod Toxicol 17: 31।-319]

sion at proestrus and estrus, and E2 alone did not induce uterine CaBP-9k mRNA in this study [29]. Taken together, these results suggest the complex hormonal regulation of CaBP-9k in the uterus of different species. To date, there was no evidence that CaBP-9k gene may be regulated by E2 in female reproductive tract of mice. In the recent study, we demonstrated that RU486, a P4 antagonist, induced a significant decrease in CaBP-9k mRNA expression, whereas tamoxifen and ICI 182,780, an E2 antagonists, had no effect on CaBP-9k mRNA expression, suggesting that $\mathrm{P} 4$, not E2, is a key regulator of CaBP-9k mRNA expression during late pregnancy and lactation in the uterus of mice [30].

The mechanism involved in the regulation of uterine CaBP-9k gene by steroids is relatively well understood in rats. In the uterus of rats, estrogen is known to up-regulate and progesterone down-regulate the expression of CaBP$9 \mathrm{k}$ gene during estrous cycle and early pregnancy $[20,22,24,25]$. The expression level of CaBP-9k mRNA fluctuates during the estrous cycle, but shows very different expression pattern in the uterus of between rats and mice as abovementioned [29]. The mechanism of distinct regulation of CaBP-9k gene between the rat and mouse is not clear at the moment. The effect of E2 on the regulation of CaBP-9k appears to be mediated through an imperfect estrogen-responsive-like element (ERE) identified in the intron A of mouse CaBP-9k gene $[8,24]$. The regulation of this gene is known to be mediated by an $\mathrm{E} 2$ response element located at the first intron of rat CaBP-9k gene [31]. Recently, cloning of intron A of the mouse CaBP-9k gene have revealed single-base difference in the ERE compared to that of the rat [32]. This may partially explain the observed difference in the hormonal regulation of CaBP$9 \mathrm{k}$ gene in the uterus of between rats and mice. In addition, a distinct regulation of porcine CaBP-9k gene in the uterus is explained by no presence of a functional ERE within intron A region [26]. However, we can not rule out the possibility of involvement of other unknown cell-, tissue-, and species-specific factors in the CaBP-9k gene expression. This idea is supported by the finding that E2 regulation of CaBP-9k gene in rats was only uterine-specific and this does not occur in the intestine [17]. Although the putative ERE failed to bind to the estrogen receptor (ER) from the mouse uterus, we isolated mouse genomic clones of the CaBP-9k gene and analyzed their expression in the mouse uterus [33]. In addition, we found a promoter region of CaBP-9k gene containing the putative progesterone response element (PRE) and its expression was stimulated by $\mathrm{P} 4$, suggesting that the mouse uterine CaBP-9k gene is expressed under the control of a PRE [33]. In the recent study, we demonstrated that P4 and PR may be a dominant factor in the regulation of CaBP-9k and E2 and ER $\alpha$ can also influence the expression of CaBP-9k gene via an indirect pathway in the uterus of immature mice [34]. Currently, endocrine disruptorinduced expression of CaBP-9k mRNA and protein was reversed or abolished by pretreatment with RU486 or ICI 182,780 , suggesting that these synthetic chemicals may have both progestogenic and estrogenic properties by acting through PR or ER in the induction of uterine CaBP-9k mRNA and protein in the uterus of immature mice [35].

\section{Uterine induction of CaBP-9k as a biomarker for endocrine disruption}

Endocrine disruptors (EDs) are environmental chemicals that interfere with physiological systems, adversely affecting hormone balance (endocrine system) or disrupting normal function in the organs that hormones regulate or modulate, for example, female and male reproductive system [36]. Representative example of suspected environmental estrogenic EDs includes the drugs which have been specifically designed to treat hormone imbalance in humans. These estrogenic compounds, including octylphenol (OP), nonylphenol (NP), bisphenol A (BPA), and methoxychlor (MXC), can also be transferred through the placenta to the fetus and through breast milk to infants $[11,13,37]$. Screening methods to detect endocrine disrupters have been evaluated by many groups, i.e. the receptor binding assay, reporter gene assay, and immature 

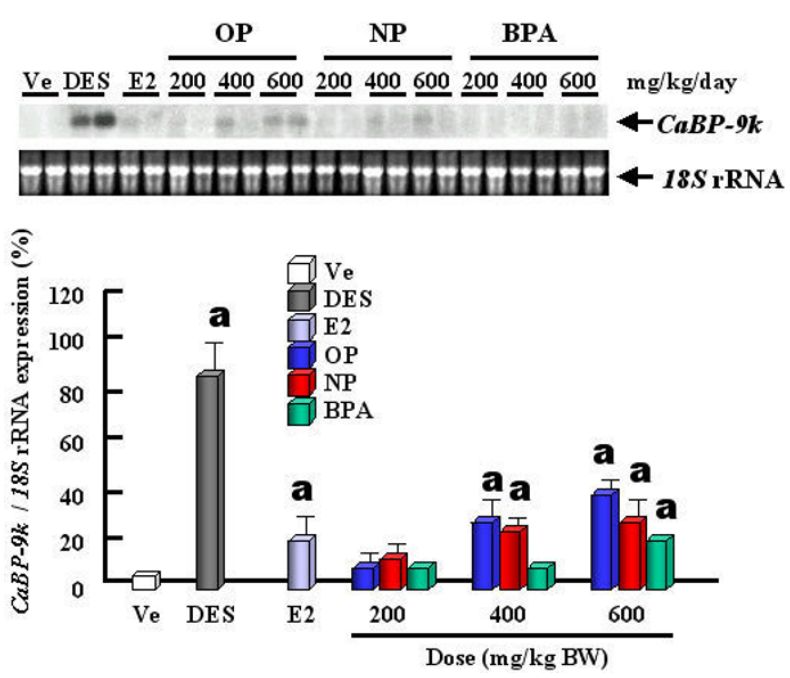

Figure 3

Induction of CaBP-9k mRNA expression in fetal uterus by estrogenic compounds. The values represent means \pm SD. a, $\mathrm{P}<0.05$ vs. vehicle. [Reproduced with permission from Hong EJ, Choi KC, Jeung E-B 2003 Maternal-fetal transfer of endocrine disruptors in the induction of Calbindin-D9k mRNA and protein during pregnancy in rat model. Mol Cell Endocrinol 212: 63-72]

rat uterotrophic assay. The reporter gene assay has many benefits as a promising prescreening procedure, because this assay could be performed as a high throughput screening process to detect an endocrine disruptor from thousands of chemicals and no use of experimental animals is required [38]. To screen estrogenic chemicals in the induction of endocrine disruption, genetically sensitive animal models, mice and rats, should be developed. Efforts to identify the mechanisms of endocrine disruption by estrogenic chemicals need to be supported for optimal test methods for thousands of potential chemicals in reproductive development and function [39]. Thus, we have recently established a sensitive method to detect CaBP-9k mRNA and protein using immature rats, which can be used as a biomarker for endocrine disruptors, thus, we introduce our current results in regard to estrogenic effect of endocrine disruptors in the uterus of immature rats [12]. Among the assays for the estrogenic activity of chemicals, an assay to detect an endogenous gene expression that measures estrogen-induced changes either in cultured cells or in selected tissues from exposed animals has been proposed and is widely being used. In our previous study, we demonstrated that phthalate esters exhibit a weak estrogenic activity in vitro assay at high concentrations. Although phthalates resulted in an increase in MCF7 cell proliferation by estrogenic effect, they could not induce CaBP-9k expression in vivo system following oral treatments, assuming that these phthalates are easily
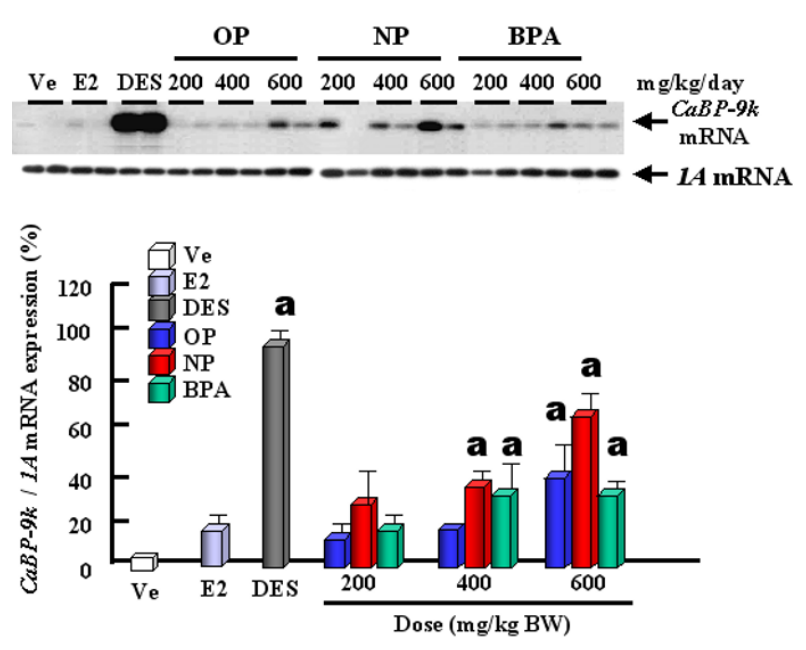

\section{Figure 4}

Effect of endocrine disruptors on the induction of CaBP-9k mRNA in neonatal uterus. RT-PCR/Southern blot analysis for CaBP-9k mRNA on day 6 of lactation was performed as previously described. The values represent means $\pm \operatorname{SD}(n=5)$. a, $P<0.05$ vs. vehicle (VE). [Reproduced with permission from Hong E-J, Choi KC, Jung YW, Leung PCK, Jeung E-B 2004 Transfer of maternally injected endocrine disruptors through breast milk during lactation induces neonatal Calbindin-D9k in the rat model. Reprod Toxicol 18: 66I-668]

metabolized to inactive forms in vivo system. These results suggest that a conflict may exist in estrogenic effect by various phthalates between in vitro and in vivo models related to the expression of CaBP-9k [40].

The expression levels of CaBP-9k mRNA and protein are strongly up-regulated by estrogenic compounds (OP, NP and BPA) and E2 itself in the uterus of immature rats (Fig. 2 ), indicating that CaBP-9k can be a useful biomarker for detection of the estrogenicity of putative estrogenic compounds. Thus, regarding to risk assessment, we propose that CaBP-9k mRNA and protein assay in the immature rat uterus can be a very sensitive and powerful tool to identify compounds with estrogenic activity when used in combination with classical assays $[11,23]$. Treatments of dams with OP, NP and BPA resulted in an increase of CaBP-9k mRNA and protein in maternal and fetal uteri (Fig. 3) of immature rats [13]. These results demonstrate that maternally injected estrogenic compounds resulted in an increase of CaBP-9k mRNA and/or protein in the maternal tissues (uterus and placenta) and fetal uterus during late pregnancy, suggesting that placenta may not be a reliable barrier against these estrogenic compounds for fetal health [13]. The uterus is a highly estrogenresponsive tissue, which can be measured through changes in CaBP-9k expression. In addition, we investigated the potential for estrogenic compounds, OP, NP, 


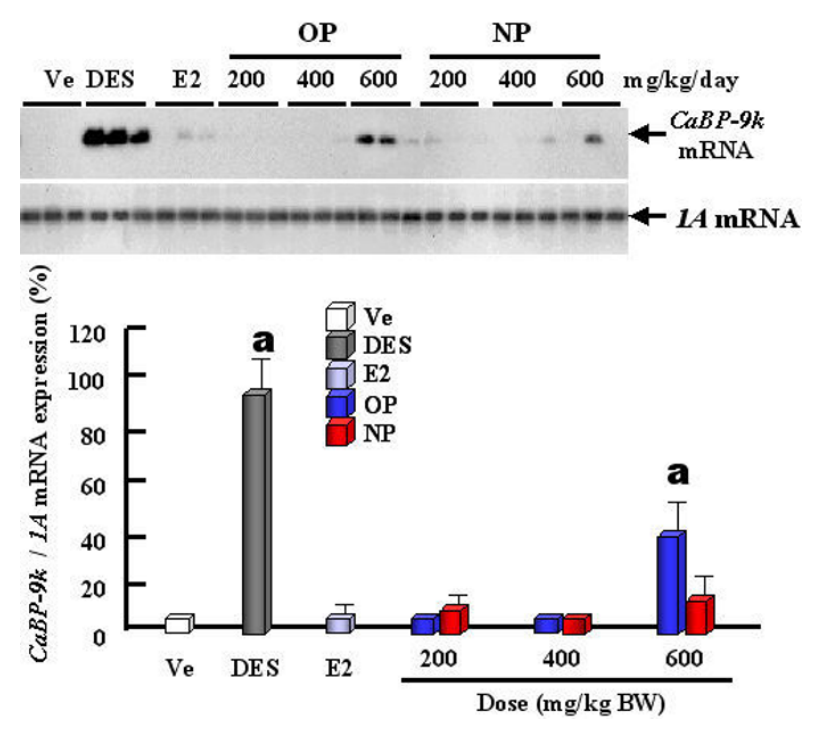

\section{Figure 5}

Effect of OP and NP on the induction of CaBP-9k mRNA in neonatal uterus. RT-PCR/Southern blot assay was performed during lactation period in neonatal uterus. The values represent means \pm SD. a, $P<0.05$ vs. vehicle. [Reproduced with permission from Hong EJ, Choi KC, Jeung EB 2004 Induction of Calbindin- $D_{9 k} m R N A$ and protein by maternal exposure to alkylphenols during late pregnancy in maternal and postnatal uteri of rats. Biol Reprod 71: 669-675]

BPA, diethylstilbestrol (DES) and E2 to be transferred through breast milk from the dam to the neonate during lactation via measuring the induction of CaBP-9k in uterine tissue [14]. These results indicate that these compounds have an estrogenic effect on the maternal uterus during the lactation period, as shown by the induction of both CaBP-9k mRNA and protein. There was a significant increase in CaBP-9k mRNA in neonatal uterus when the dams were treated with high doses of estrogenic compounds, but protein levels of CaBP-9k were undetectable (Fig. 4). Taken together, these findings suggest that maternally injected estrogenic compounds may be transferred to neonates through breast milk and thus, affect uterine function, as shown by the induction of CaBP-9k gene expression in neonatal uterus [14]. In addition, we recently examined the effect of OP, NP and BPA on the expression of CaBP-9k following maternal exposures during late pregnancy in maternal and fetal uterus $[15,41]$. The expression of CaBP-9k mRNA was also induced following treatment with a high dose $(600 \mathrm{mg} / \mathrm{kg} \mathrm{BW})$ of OP transferred from mother exposed to fetuses during late pregnancy and persisted in 5 day of lactation (Fig. 5). In parallel with mRNA level, the expression level of CaBP-9k protein was significantly induced by treatment with a high dose of OP and NP in the maternal uterus by immunohistochemistry (Fig. 6). In conclusion, the maternal expo-

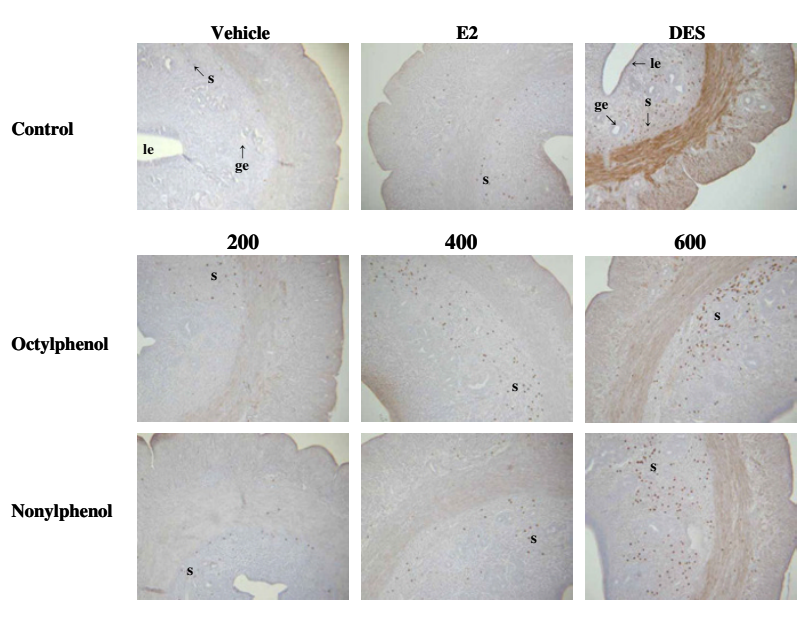

\section{Figure 6}

Localization of CaBP-9k protein by immunohistochemicalstaining in maternal uterus. Immuno-reactivity of CaBP-9k protein expression following treatment with OP and NP was investigated in endometrium and smooth myometrial fibers dose-dependently. Especially, these proteins that are widely spaced through the stromal cells in endometrium s, stroma cells; le, Luminal epithelial cell; ge, glandular epithelial cell. Magnification $\times 100$. [Reproduced with permission from Hong EJ, Choi KC, Jeung EB 2004 Induction of Calbindin-- ${ }_{9 k}$ mRNA and protein by maternal exposure to alkylphenols during late pregnancy in maternal and postnatal uteri of rats. Biol Reprod 7I: 669-675]

sures to OP, NP and BPA during late pregnancy increased the expression levels of CaBP-9k mRNA and protein in maternal or neonatal uteri, suggesting that the absorption and distribution of environmental estrogenic compounds in maternal and neonatal uteri are extremely rapid, and these chemicals can easily pass though placenta during pregnancy to affect functions of neonatal reproductive tissues $[15,41]$. In addition, a novel in vivo model was introduced to detect both estrogenic and progestogenic activities of EDs in the induction of CaBP-9k mRNA and protein in the uterus of immature mice [35].

Genistein, a phytoestrogen, has been shown to have relatively 20 -fold higher binding affinity to the $\operatorname{ER} \beta$ than $\mathrm{ER}^{\alpha}$ by a solid-phase binding assay [42]. To determine which $\mathrm{ER}$ is involved in the induction of CaBP-9k gene, we employed genistein as a potent ER $\beta$ agonist to clarify its effect on uterine CaBP-9k regulation [43]. Both CaBP-9k mRNA and protein levels were significantly induced by genistein in the uterus of immature rats. It is of interest that the pre-treatment of immature rats with ICI 182,780 (ICI), followed by genistein or E2, completely blocked 

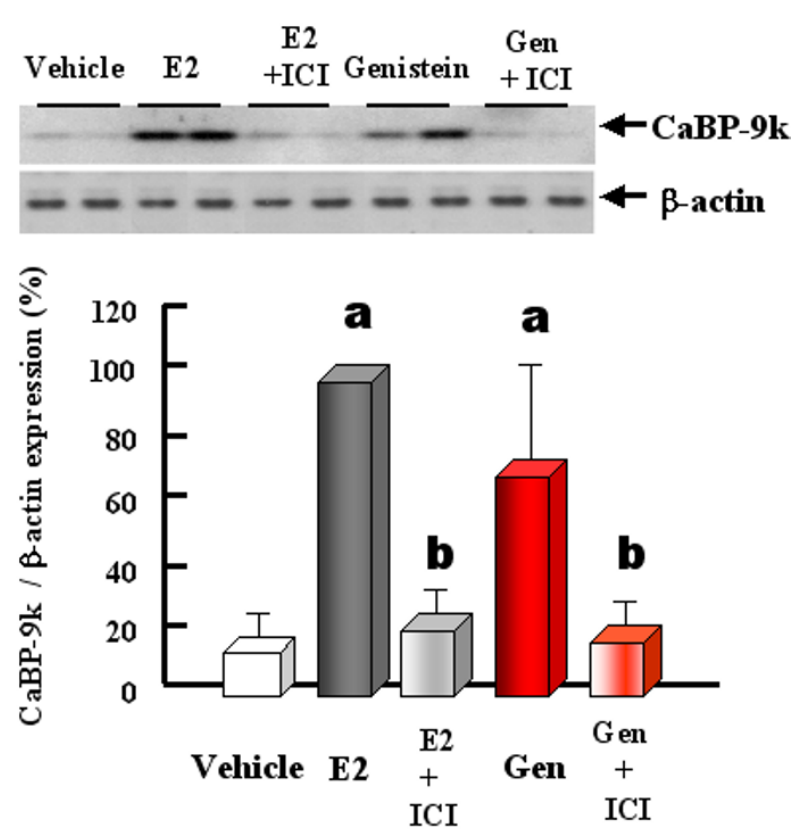

\section{Figure 7}

Effect of $\mathrm{ICl}$ on genistein-induced uterine CaBP-9k protein expression. Immature rats were injected $\mathrm{SC}$ with $\mathrm{ICl}$ at 30 min prior to genistein ( $40 \mathrm{mg} / \mathrm{kg}$ BW per day) or E2, and euthanized $24 \mathrm{~h}$ after final injection. The level of CaBP-9k protein was analyzed by immunoblot analysis. The values represent means $\pm S D$. a, $P<0.05$ vs. vehicle; $b, P<0.05$ vs. genistein or E2 treatment only [Reproduced with permission from Lee GS, Choi KC, Kim HJ, Jeung EB 2004 Effect of genistein on the expression of Calbindin- $D_{9 k}$ as a potential estrogenic compound in the uterus of immature rats through estrogen receptors. Toxicol Sci 82: 45I-457]

genistein- and E2-induced CaBP-9k protein in this tissue as demonstrated in Fig. 7. In addition, genistein was demonstrated to induce ER $\alpha$ protein, but not ER $\beta$ or PR mRNA, an E2-responsive gene, in this tissue. These results imply that genistein, an ER $\beta$ ligand, may regulate $C a B P-9 k$ gene through $\mathrm{ER} \alpha$ pathway and $\mathrm{ER} \alpha$ may be a key mediator in the induction of uterine CaBP-9k gene in immature rats [43]. To support an involvement of ER $\alpha$-dependent pathway by EDs, we demonstrated that uterine CaBP-9k gene expression is mainly mediated by propyl pyrazole triol (PPT), an ER $\alpha$-selective ligand, in a dose- and timedependent manner, in the uterus of immature rats [44]. In contrast, no significant alteration in the uterine $\mathrm{CaBP}-9 \mathrm{k}$ gene was observed after diarylpropionitrile (DPN), an ER $\beta$-selective ligand. In addition, an estrogenicity of PPT in inducing CaBP-9k expression was completely blocked by ICI 182,780 ; which suggests that uterine CaBP-9k is solely enhanced though ER $\alpha$. Taken together, these results indicate that uterine CaBP-9k is induced by E2 and endocrine disrupting chemicals via ER $\alpha$ pathway, but not ER $\beta$, in the uterus of immature rats [44].

\section{Placental expression of CaBP-9k}

Transport of $\mathrm{Ca} 2+$ through placenta is responsible for developing fetus, and CaBP-9k appears to play an important role in the regulation of $\mathrm{Ca} 2+$ from the mother to the fetus during pregnancy. However, the role of CaBP-9k is unknown to date in placenta during pregnancy. A recent study demonstrated that CaBP-9k transcript is present in cytotrophoblast cells and syncytiotrophoblasts of human term placenta, with a lower expression in cytotrophoblast cells as compared to syncytiotrophoblasts [45]. In addition, CaBP-9k protein was present in cytotrophoblast and syncytiotrophoblast placental tissue sections as well as in cultured cells, indicating that CaBP-9k is unequivocally expressed by trophoblast cells from human term placenta [45]. The expression of CaBP-9k gene has been investigated in the placenta of other species [26,46-48]. The high level of CaBP-9k has been localized to epithelial cells of the yolk sac and endodermal cells of the placenta [16]. The expression of CaBP-9k mRNA was not detectable by Northern blot analysis, while this transcript was detected in porcine myometrium and placenta by RT-PCR [26]. As previously described, CaBP-9k mRNA has been also localized in the trophoblasts in various species. It is hypothesized that CaBP-9k plays a role in calcium transfer and fetal growth by parallel gestational changes in placental CaBP-9k which reflects the fetal accumulation of calcium. An increased level of CaBP-9k gene in the caruncular epithelium during the last trimester is in response to the increasing need for calcium to supply the fetal skeleton with mineralization, suggesting that CaBP9k may play a role in transporting calcium across the placenta in cattle [48]. In the placenta of mice, the distinct regulation of CaBP-9k has been demonstrated in the placenta compared to other tissues such as intestine and kidney, indicating that the expression of this gene is not dependent on Vitamin D receptor [49]. Recently we demonstrated the expression of CaBP-9k for the first time in mouse placenta and extra-embryonic membrane separately, and CaBP-9k mRNA may be regulated by sex steroid hormones (E2 and $\mathrm{P} 4)$ and their receptors through complex pathway in these tissues [50].

\section{Concluding Remarks}

Although CaBP-9k is mainly expressed in female reproductive tissues, i.e., uterus and placenta of various species, the role of CaBP-9k remains unknown. It can be hypothesized that uterine CaBP-9k may be involved in controlling myometrial activity related with intracellular calcium level and placental CaBP-9k plays a role in calcium transfer from the mother to the fetus for fetal growth. It appears that CaBP-9k gene is not under the control of vitamin D 
in the uterus despite the presence of vitamin $\mathrm{D}$ receptors in this tissue; instead it is under the control of the sex steroid hormones. The hormonal mechanism controlling uterine CaBP-9k gene is relatively well understood in the rat. In the uterus of rats, estrogen is known to up-regulate and progesterone down-regulate the expression of CaBP$9 \mathrm{k}$ gene during estrous cycle and pregnancy. However, the recent studies demonstrated that CaBP-9k is mainly regulated by progesterone, not estrogen in the uterus of mice because of lack of responsiveness caused by a single-base difference in the ERE of mouse CaBP-9k gene compared to that of rats. Until now, a few studies demonstrated the expression and regulation of CaBP-9k gene in the placenta of various species. It appears that CaBP-9k mRNA may be regulated by sex steroid hormones (E2 and P4) and their receptors through complex pathway in these tissues. We assumed that $\mathrm{ER} \alpha$ may be a key mediator in uterine CaBP$9 k$ gene induction in immature rats. The elucidation of other factors that regulate CaBP-9k mRNA will further provide insight into the understanding of regulation of CaBP-9k in these tissues, and its roles in the control of reproductive functions.

The uterus is a highly estrogen-responsive tissue, which can be measured through changes in CaBP-9k expression. We demonstrated that the expression levels of CaBP-9k mRNA and protein are induced by estrogenic chemicals, so called "endocrine disruptors", in the uterus of immature rats. In addition, maternally injected estrogenic compounds resulted in an increase of CaBP-9k mRNA and/or protein in the fetal uterus during late pregnancy, suggesting that placenta may not be a reliable barrier against these estrogenic compounds for fetal health. It is of interest that maternally injected estrogenic compounds may be transferred to neonates through breast milk and thus affect uterine function, as shown by the induction of CaBP-9k gene expression in neonatal uterus. The expression of CaBP-9k mRNA and/or protein is an excellent biomarker to detect an estrogenic chemical in the uterus of immature rats which we developed and established. Availability of this gene using immature rats will provide an insight of risk assessment for estrogenic and progestogenic chemicals in our environment.

\section{Acknowledgements}

This work was supported by the research grant of the Chungbuk National University in 2005. The authors would like to thank Mr. Geun-Shik LEE (College of Veterinary Medicine, Chungbuk National University) for editing the figures.

\section{References}

I. Christakos S, Gabrielides C, Rhoten WB: Vitamin D-dependent calcium binding proteins: chemistry, distribution, functional considerations, and molecular biology. Endocr Rev 1989, 10:3-26.

2. Jeung EB, Krisinger J, Dann JL, Leung PC: Molecular cloning of the full-length cDNA encoding the human calbindin-D9k. FEBS Lett 1992, 307:224-228.
3. Jeung EB, Leung PC, Krisinger J: The human calbindin-D9k gene. Complete structure and implications on steroid hormone regulation. J Mol Biol 1994, 235: I23I-I238.

4. Armbrecht HJ, Boltz M, Strong R, Richardson A, Bruns ME, Christakos S: Expression of calbindin-D decreases with age in intestine and kidney. Endocrinology 1989, I 25:2950-2956.

5. Mathieu CL, Burnett SH, Mills SE, Overpeck JG, Bruns DE, Bruns ME: Gestational changes in calbindin-D9k in rat uterus, yolk sac, and placenta: implications for maternal-fetal calcium transport and uterine muscle function. Proc Natl Acad Sci U S A 1989, 86:3433-3437.

6. Mathieu CL, Mills SE, Burnett SH, Cloney DL, Bruns DE, Bruns ME: The presence and estrogen control of immunoreactive calbindin-D9k in the fallopian tube of the rat. Endocrinology 1989 , I 25:2745-2750.

7. Seifert MF, Gray RW, Bruns ME: Elevated levels of vitamin Ddependent calcium-binding protein (calbindin-D9k) in the osteosclerotic (oc) mouse. Endocrinology 1988, 122: 1067-1073.

8. Darwish HM, DeLuca HF: Identification of a 1,25-dihydroxyvitamin D3-response element in the 5'-flanking region of the rat calbindin D-9k gene. Proc Natl Acad Sci U S A 1992, 89:603-607.

9. Wasserman RH, Fullmer CS: On the molecular mechanism of intestinal calcium transport. Adv Exp Med Biol I 989, 249:45-65.

10. Krisinger J, Strom M, Darwish HD, PerIman K, Smith C, DeLuca HF: Induction of calbindin-D $9 \mathrm{k}$ mRNA but not calcium transport in rat intestine by I,25-dihydroxyvitamin D3 24-homologs. J Biol Chem 1991, 266:1910-1913.

II. An BS, Choi KC, Kang SK, Hwang WS, Jeung EB: Novel Calbindin$D(9 k)$ protein as a useful biomarker for environmental estrogenic compounds in the uterus of immature rats. Reprod Toxicol 2003, 17:311-319.

12. Choi KC, Jeung EB: The biomarker and endocrine disruptors in mammals. J Reprod Dev 2003, 49:337-345.

13. Hong EJ, Choi KC, Jeung EB: Maternal-fetal transfer of endocrine disruptors in the induction of Calbindin-D9k mRNA and protein during pregnancy in rat model. Mol Cell Endocrinol 2003, 2I 2:63-72.

14. Hong EJ, Choi KC, Jung YW, Leung PC, Jeung EB: Transfer of maternally injected endocrine disruptors through breast milk during lactation induces neonatal Calbindin-D9k in the rat model. Reprod Toxicol 2004, 18:661-668.

15. Hong EJ, Choi KC, Jeung EB: Induction of Calbindin-D9k mRNA and protein by maternal exposure to alkylphenols during late pregnancy in maternal and neonatal uteri of rats. Biol Reprod 2004, 71:669-675.

16. Bruns ME, Kleeman E, Mills SE, Bruns DE, Herr JC: Immunochemical localization of vitamin D-dependent calcium-binding protein in mouse placenta and yolk sac. Anat Rec 1985, 213:5|4-7, 532-5.

17. Delorme AC, Danan JL, Acker MG, Ripoche MA, Mathieu H: In rat uterus 17 beta-estradiol stimulates a calcium-binding protein similar to the duodenal vitamin D-dependent calciumbinding protein. Endocrinology 1983, I I 3:1340-1347.

18. Warembourg M, Perret $C$, Thomasset $M$ : Analysis and in situ detection of cholecalcin messenger RNA (9000 Mr CaBP) in the uterus of the pregnant rat. Cell Tissue Res 1987, 247:5I-57.

19. Inpanbutr N, Miller EK, Petroff BK, lacopino AM: CaBP9K levels during the luteal and follicular phases of the estrous cycle in the bovine uterus. Biol Reprod 1994, 50:56I-57I.

20. L'Horset F, Blin C, Brehier A, Thomasset M, Perret C: Estrogeninduced calbindin- $D 9 \mathrm{k}$ gene expression in the rat uterus during the estrous cycle: late antagonistic effect of progesterone. Endocrinology 1993, 132:489-495.

2I. L'Horset F, Perret C, Brehier A, Thomasset M: 17 beta-estradiol stimulates the calbindin-D9k (CaBP9k) gene expression at the transcriptional and posttranscriptional levels in the rat uterus. Endocrinology 1990, 1 27:289|-2897.

22. Krisinger J, Dann JL, Currie WD, Jeung EB, Leung PC: CalbindinD9k MRNA is tightly regulated during the estrous cycle in the rat uterus. Mol Cell Endocrinol 1992, 86: I 19-123.

23. An BS, Kang SK, Shin JH, Jeung EB: Stimulation of calbindin-D(9k) mRNA expression in the rat uterus by octyl-phenol, nonylphenol and bisphenol. Mol Cell Endocrinol 2002, I9I:177-I86.

24. L'Horset F, Blin C, Colnot S, Lambert M, Thomasset M, Perret C: Calbindin-D9k gene expression in the uterus: study of the two messenger ribonucleic acid species and analysis of an 
imperfect estrogen-responsive element. Endocrinology 1994, 134: II-18.

25. Krisinger J, Setoyama T, Leung PC: Expression of calbindin-D9k in the early pregnant rat uterus: effects of RU $\mathbf{4 8 6}$ and correlation to estrogen receptor mRNA. Mol Cell Endocrinol 1994, 102:15-22.

26. Krisinger J, Jeung EB, Simmen RC, Leung PC: Porcine calbindin$D 9 k$ gene: expression in endometrium, myometrium, and placenta in the absence of a functional estrogen response element in intron A. Biol Reprod 1995, 52:115-123.

27. Yun SM, Choi KC, Kim IH, An BS, Lee GS, Hong EJ, Oh GT, Jeung EB: Dominant expression of porcine Calbindin-D9k in the uterus during a luteal phase. Mol Reprod Dev 2004, 67:25I-256.

28. Tatsumi K, Higuchi T, Fujiwara H, Nakayama T, Itoh K, Mori T, Fujii $\mathrm{S}$, Fujita J: Expression of calcium binding protein D-9k messenger RNA in the mouse uterine endometrium during implantation. Mol Hum Reprod 1999, 5:153-161.

29. Nie GY, Li Y, Wang J, Minoura H, Findlay JK, Salamonsen LA: Complex regulation of calcium-binding protein D9k (calbindin$D(9 k)$ ) in the mouse uterus during early pregnancy and at the site of embryo implantation. Biol Reprod 2000, 62:27-36.

30. An BS, Choi KC, Kang SK, Lee GS, Hong EJ, Hwang WS, Jeung EB: Mouse calbindin- $\mathrm{D}(9 \mathrm{k})$ gene expression in the uterus during late pregnancy and lactation. Mol Cell Endocrinol 2003, 205:79-88.

31. Darwish H, Krisinger J, Furlow JD, Smith C, Murdoch FE, DeLuca HF: An estrogen-responsive element mediates the transcriptional regulation of calbindin $\mathrm{D}-9 \mathrm{~K}$ gene in rat uterus. J Biol Chem 1991, 266:55I-558.

32. Krisinger J, Dann JL, Applegarth O, Currie WD, Jeung EB, Staun M, Leung PC: Calbindin-D9k gene expression during the perinatal period in the rat: correlation to estrogen receptor expression in uterus. Mol Cell Endocrinol 1993, 97:6I-69.

33. Lee KY, Oh GT, Kang JH, Shin SM, Heo BE, Yun YW, Paik SG, Krisinger J, Leung PC, Jeung EB: Transcriptional regulation of the mouse calbindin-D9k gene by the ovarian sex hormone. Mol Cells 2003, 16:48-53.

34. An BS, Choi KC, Hong EJ, Jung YW, Manabe N, Jeung EB: Differential transcriptional and translational regulations of calbindinD9k by steroid hormones and their receptors in the uterus of immature mice. J Reprod Dev 2004, 50:445-453.

35. Jung YW, Hong E], Choi KC, Jeung EB: Novel progestogenic activity of environmental endocrine disruptors in the upregulation of calbindin-D9k in an immature mouse model. Toxicol Sci 2005, 83:78-88.

36. Daston GP, Cook JC, Kavlock RJ: Uncertainties for endocrine disrupters: our view on progress. Toxicol Sci 2003, 74:245-252.

37. Laws SC, Carey SA, Ferrell JM, Bodman G], Cooper RL: Estrogenic activity of octylphenol, nonylphenol, bisphenol $A$ and methoxychlor in rats. Toxicol Sci 2000, 54: 154-167.

38. Takeyoshi M, Yamasaki K, Sawaki M, Nakai M, Noda S, Takatsuki M: The efficacy of endocrine disruptor screening tests in detecting anti-estrogenic effects downstream of receptor-ligand interactions. Toxicol Lett 2002, I 26:91-98.

39. Spearow JL, Barkley M: Reassessment of models used to test xenobiotics for oestrogenic potency is overdue. Hum Reprod 200I, 16:1027-1029.

40. Hong EJ, Ji YK, Choi KC, Manabe N, Jeung EB: Conflict of estrogenic activity by various phthalates between in vitro and in vivo models related to the expression of Calbindin-D9k. J Reprod Dev 2005, 5 I:253-263.

4l. Hong EJ, Choi KC, Jeung EB: Maternal Exposure to Bisphenol A during Late Pregnancy Resulted in an Increase of CalbindinD9k mRNA and Protein in Maternal and Postnatal Rat Uteri. J Reprod Dev 2005, In press:.

42. Kuiper GG, Lemmen JG, Carlsson B, Corton JC, Safe SH, van der Saag PT, van der Burg B, Gustafsson JA: Interaction of estrogenic chemicals and phytoestrogens with estrogen receptor beta. Endocrinology 1998, 139:4252-4263.

43. Lee GS, Choi KC, Kim HJ, Jeung EB: Effect of genistein as a selective estrogen receptor beta agonist on the expression of Calbindin-D9k in the uterus of immature rats. Toxicol Sci 2004, 82:45I-457.

44. Lee GS, Kim HJ, Jung YW, Choi KC, Jeung EB: Estrogen receptor alpha pathway is involved in the regulation of Calbindin-D9k in the uterus of immature rats. Toxicol Sci 2005, 84:270-277.
45. Belkacemi L, Gariepy G, Mounier C, Simoneau L, Lafond J: Calbindin-D9k (CaBP9k) localization and levels of expression in trophoblast cells from human term placenta. Cell Tissue Res 2004, 3 I 5: I07-II7.

46. Jeung EB, Krisinger J, Dann JL, Leung PC: Cloning of the porcine Calbindin-D9k complementary deoxyribonucleic acid by anchored polymerase chain reaction technique. Biol Reprod 1992, 47:503-508.

47. Jeung EB, Fan NC, Leung PC, Herr JC, Freemerman A, Krisinger J: The baboon expresses the calbindin-D9k gene in intestine but not in uterus and placenta: implication for conservation of the gene in primates. Mol Reprod Dev 1995, 40:400-407.

48. Reiswig JD, Frazer GS, Inpanbutr N: Calbindin-D9k expression in the pregnant cow uterus and placenta. Histochem Cell Biol I995, 104:169-174.

49. Shamley DR, Veale G, Pettifor JM, Buffenstein R: Trophoblastic giant cells of the mouse placenta contain calbindin-D9k but not the vitamin D receptor. I Endocrinol 1996, I50:25-32.

50. An BS, Choi KC, Lee GS, Leung PC, Jeung EB: Complex regulation of Calbindin-D9k in the mouse placenta and extra-embryonic membrane during mid- and late pregnancy. Mol Cell Endocrinol 2004, 2 । 4:39-52.
Publish with BioMed Central and every scientist can read your work free of charge

"BioMed Central will be the most significant development for disseminating the results of biomedical research in our lifetime. "

Sir Paul Nurse, Cancer Research UK

Your research papers will be:

- available free of charge to the entire biomedical community

- peer reviewed and published immediately upon acceptance

- cited in PubMed and archived on PubMed Central

- yours - you keep the copyright

Submit your manuscript here:

http://www.biomedcentral.com/info/publishing_adv.asp 